\title{
Soil genesis along a chronosequence on marine terraces in eastern Taiwan
}

\author{
Chen-Chi Tsai ${ }^{\text {a }}$, Heng Tsai ${ }^{b}$, Zeng-Yei Hseu ${ }^{\text {c,* }}$, Zueng-Sang Chen ${ }^{\mathrm{d}}$ \\ a Department of Natural Resources, National I-Lan University, I-Lan 26047, Taiwan \\ b Department of Geography, National Changhua University of Education, Changhua 50058, Taiwan \\ ${ }^{\mathrm{c}}$ Department of Environmental Science and Engineering, National Pingtung University of Science and Technology, Pingtung 91201 , Taiwan \\ d Department of Agricultural Chemistry, National Taiwan University, Taipei, 10617, Taiwan
}

\begin{abstract}
Soil chronosequences developed on elevated marine terraces are ideal for studying changes in soil-forming processes with time. The coastal range of eastern Taiwan is a product of active arc-continent collision. Vertisols, Mollisols and Entisols are generally found on the different levels of marine terraces herein, but no detailed investigations of soil chronosequence have been conducted by integrating field morphology, physiochemical characterization, micromorphology and mass-balance interpretations. Five soil pedons were selected on the three marine terraces including Tt-1 and Tt-2 pedons (Typic Hapluderts) on the first higher level with the oldest soil age (9-10 ka), Tt-3 (Vertic Hapludolls) and Tt-4 pedons (Typic Hapludolls) on the second intermediate level (5-6 ka), and Tt-5 pedon (Typic Udipsamments) on the third lower level with the youngest soil age $(\leq 3.5 \mathrm{ka})$. The morphological characteristics showed that strongly developed angular blocky structures, pressure faces and slickensides are more common in higher terrace soils than in lower terrace soils. In this study, depth to C horizon, solum thickness, and thickness of the clay-enriched zone increase with relative terrace age. Although only one to two profiles per terrace were characterized, the following soil analytical characterizations increase with time: the degree of sand grains weathering, $\mathrm{pH}\left(\mathrm{H}_{2} \mathrm{O}\right)$, organic carbon, $\mathrm{CEC}$, contents of Fe $\mathrm{d}_{\mathrm{d}}$, $\mathrm{Fe}_{\mathrm{o}}$ and $\mathrm{Mn}_{\mathrm{d}}$. Based on X-ray diffraction analysis of the clay-size fraction, soils on all terraces have a mixed mineralogy. Mica, smectite, and kaolinite have slightly increased with increasing terrace age. Furthermore, the dominant processes identified with mass-balance analysis include loss of bases (Ca and $\mathrm{Mg}$ ), iron, and clay with time. The soil properties, including analytical and mineralogical characterizations, which do not have notable changes with time are primarily due to relatively young soil age $(<10 \mathrm{ka})$.
\end{abstract}

(C) 2007 Elsevier B.V. All rights reserved.

Keywords: Marine terrace; Mass balance; Mollisols; Soil chronosequence; Vertisols

\section{Introduction}

Soil chronosequences are valuable tools for investigating rates and directions of soil and landscape evolution (Huggett, 1998; Vreeken, 1975). They are found in many landscapes, and the Quaternary marine terraces are suitable for constructing soil chronosequences. Marine terraces are ideal for studying changes in soil chronosequences, because the soil properties are time-dependent variables, which can be used as indicators of the duration of pedogenesis (Jenny, 1941). Langley-Turnbaugh and Bockheim (1998) also concluded that soil chronosequences developed on elevated marine terraces are ideal for studying changes in soil-forming processes with time. Soils on sequences

\footnotetext{
* Corresponding author. Tel.: +886 8 7740253; fax: +886 87740320 .

E-mail address: zyhseu@mail.npust.edu.tw (Z.-Y. Hseu).
}

of marine terraces have been used as chronosequences, for relative dating and coastal terrace correlation and for studying rates and processes of geochemical and pedogenic changes (Bockheim et al., 1996; Merritts et al., 1991; Moody and Graham, 1995; Muhs, 1982). Muhs (2001) indicated that soil chronosequence study has added greatly to our understanding of how soils developed over time, and such studies also provide a basis for the use of soils in establishing relative-age relations in geomorphology.

Soil properties, including solum thickness, profile clay content, profile contents of extractable $\mathrm{Fe}$ and $\mathrm{Al}$, and soil development indices derived from field soil properties, have been investigated and proposed in differentiating late Quaternary marine terrace along the Pacific Coast of the United States (Bockheim et al., 1992; Merritts et al., 1991; Muhs, 1982). Merritts et al. (1991) suggested that six pedogenic properties of 
soils, including organic carbon, soil reaction $(\mathrm{pH})$, total mass of accumulated clay, crystalline and amorphous forms of iron, and amorphous forms of aluminum, have systematic, time-dependent trends in uplifted marine terraces in northern California. Bockheim et al. (1996) suggested that the primary age-related trends of soil properties in tectonically uplifted marine terrace of southwestern Oregon include increases in the relative abundance of silt and clay, the amounts of dithionite-extractable $\mathrm{Fe}$ $\left(\mathrm{Fe}_{\mathrm{d}}\right)$ and $\mathrm{Al}\left(\mathrm{Al}_{\mathrm{d}}\right)$, and the ratio of quartz to feldspars in the very fine sand fraction. Better dated soil chronosequence studies in tropical climates show that certain key soil properties change over time, including solum thickness, solum redness, clay content, $\mathrm{Fe}_{\mathrm{d}}$, etc. (Birkeland, 1999; Muhs, 2001; Nieuwenhuyse and Van Breemen, 1997). Additionally, important changes in clay mineralogy occurred, with kaolinite content generally increasing over time and sometimes altering to gibbsite or boehmite. Muhs (2001) indicated that many soil properties in tropical regions can be potentially useful relative-age indicators in Quaternary stratigraphic studies.

Mass-balance analysis provides a means to account for the fate of elements during soil evolution by quantifying the additions, losses, translocation and transformations which occur over time (Brimhall and Dietrich, 1987; Merritts et al., 1991). Langley-Turnbaugh and Bockheim (1998) demonstrated that mass-balance analysis integrated with more traditional soil analysis can provide a clear picture of the pedogenesis process operating on marine terrace.

The eastern coast of Taiwan is situated on the Luzon arc alongside the NE-SW trending plate boundary (Ho, 1988). Differential uplifted rates along the eastern coast produced the highest terrace in its middle and southern parts (Hsieh et al., 2004; Hsu, 1988; Liew et al., 2004). Soils formed on marine terraces on the eastern coast of Taiwan provide an excellent opportunity to study the soil genesis that occurs over hundreds of thousands of years of soil formation, but no detailed investigations in these soil chronosequences have been conducted. The purpose of this paper is to integrate and evaluate soil field morphology, soil characterization, micromorphology and mass transfers during soil evolution on Holocene terraces near the middle part of the eastern coast, Taiwan. The primary objective of this study was to examine changes in soil properties over time as clues to dominant soilformation processes on marine terraces along the eastern coast of Taiwan. A secondary objective was to identify soil analytical properties useful in distinguishing the marine terraces.

\section{Materials and methods}

\subsection{Environmental setting}

Taiwan is situated in the northeast trending collision zone of the Eurasian plate and Philippine Sea plate, and the study area is located along the coast of the Pacific Ocean in eastern Taiwan, adjacent to the convergent boundary of the Eurasian plate and Philippine Sea plate (Fig. 1). Liew et al. (2004) indicated that most of the well-preserved terraces along the eastern coast were formed during the Holocene, and there are commonly 3-4 terraces. The Holocene uplift rates are typically about $5 \mathrm{~mm}$ $\mathrm{yr}^{-1}$ (Hsieh et al., 2004; Hsu, 1988; Liew et al., 2004). The active tectonics results in many marine terraces along the coast. These terraces are better developed and preserved in the middle segment of the coast. Hsu (1988) suggested three major levels for the terraces, based on the classification and correlation of the continuity of altitude and extent of the marine terrace surfaces.

The soil sampling transect is selected between the township of San-chien-wu and Chang-ping, which consists of broad and at least 3 levels of marine terraces about 35 to $80 \mathrm{~m}$ above sea level (Fig. 2). The slopes of the surfaces ranged from 2 to $5 \%$. The outcrops of the stratigraphic units from lowest to the top include the Miocene-Pliocene andesite and andesitic
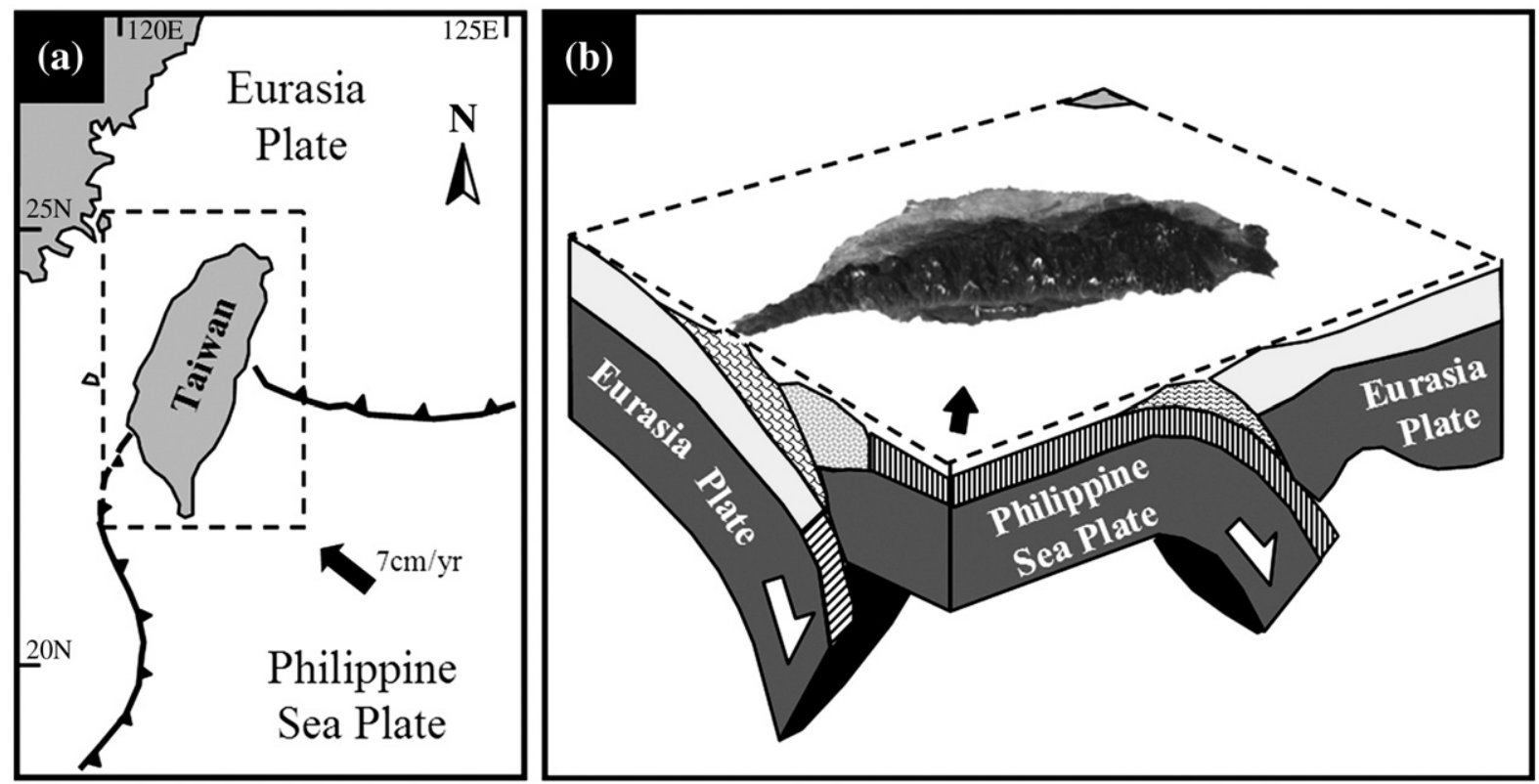

Fig. 1. Figures illustrate (a) the tectonic framework of Taiwan. (b) Three-dimensional view of the dashed box in (a). 


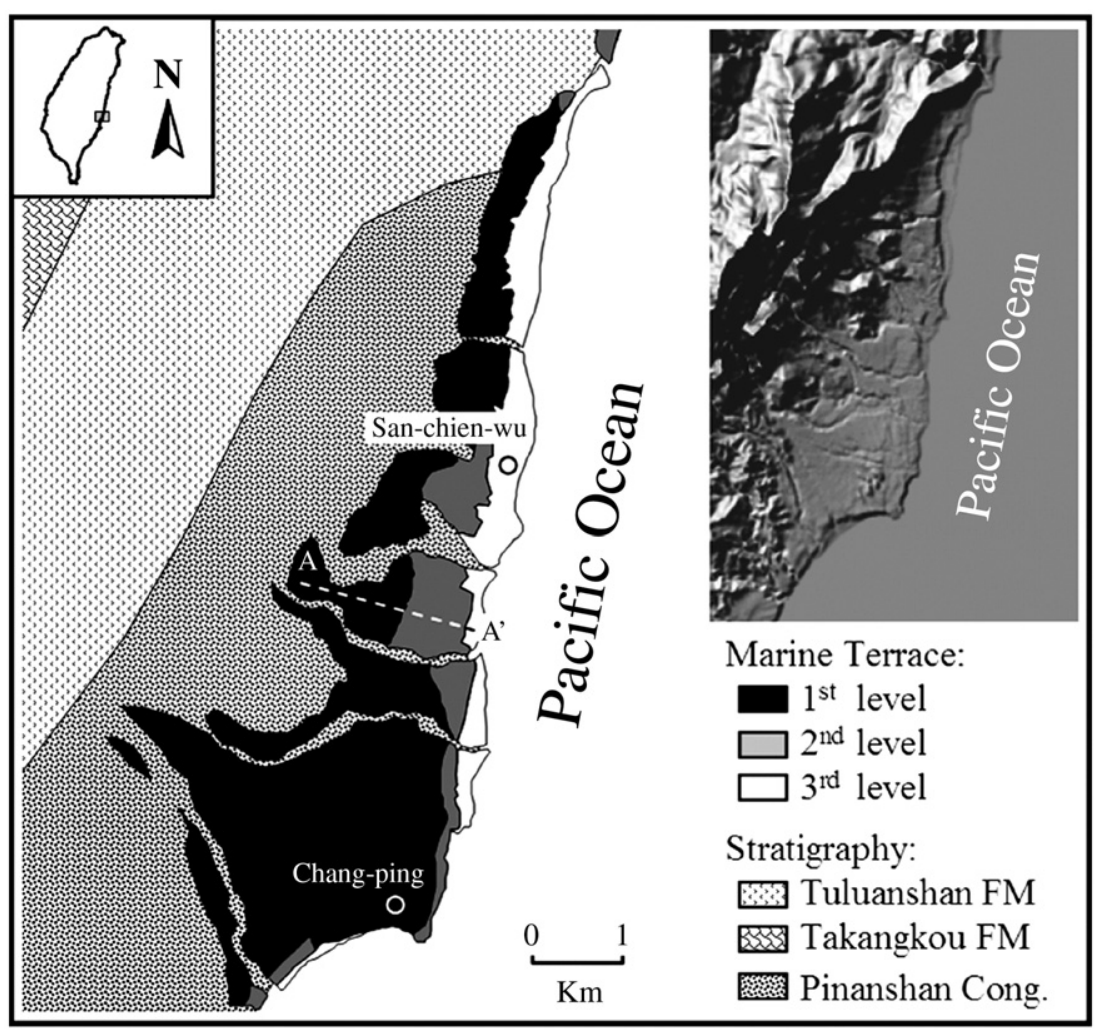

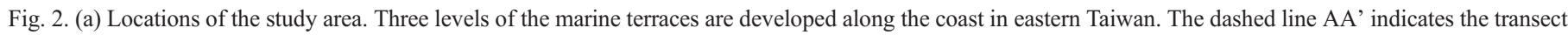
where the soil pedons are sampled. (b) The shaded relief of the study area shows the terrain of the coastal range and the marine terraces.

pyroclastics (Tuluanshan Formation), the Pliocene-Pleistocene volcaniclastic sediments (Takankou Formation), and the Pleistocene Pinanshan Conglomerate. The annual rainfall is about $1800 \mathrm{~mm}$ and the mean annual air temperature is about $22.5^{\circ} \mathrm{C}$ (ranged from 18 to $27^{\circ} \mathrm{C}$ ) in the study area. The higher annual rainfall resulted in moisture condition in soils all year round and gives a udic soil moisture regime. The mean annual air temperature suggested that the soil temperature is higher than $22{ }^{\circ} \mathrm{C}$ and gives a hyperthermic soil temperature regime based on the U.S. Soil Survey Manual (Soil Survey Division Staff, 1993). Cropland, especially lowland rice, has been the major land use type but now is in fallow.

\subsection{Field description and sampling}

Dating soils is difficult and provides in many cases only approximations of the true age of a soil profile. Sometimes soils can be dated by ${ }^{14} \mathrm{C}$ dating of soil organic matter (Matthews and Dresser, 1983) or buried A horizons. However, soil age estimations are usually based on the position of a soil in the landscape in relation to known geological events, e.g. uplift rates of terraces, or by dating parent material or under- or overlaying deposits (Nieuwenhuyse and Van Breemen, 1997). Five soil pedons were selected on the 1 st to the 3 rd levels of the marine terraces along a transect in this study (Table 1). The soil parent materials of the 1 st and 2 nd levels are the sandstone, alternation of sandstone and shale, and part of conglomerate from the abovementioned Tuluanshan Formation; but in the 3rd level, volcaniclastic gravel and beach sand with mixed sandstone and alternation of sandstone and shale materials are the main soil parent materials. However, all the parent materials consist of similar mineralogy (Shih et al., 1988), and thus the present soils are in a chronosequence. The soil ages of five pedons were based on Hsieh et al. (2004). The results of soil age estimation suggests that the Tt- 1 and Tt- 2 pedons located on the 1st level terrace were the oldest soils (about 9-10 ka), followed by the Tt-3 and Tt-4 pedons on the 2 nd level with younger soil age about 5-6 ka, and Tt-5 pedon on the 3rd level with the youngest soil age about $\leq 3.5 \mathrm{ka}$. Soils profile description was

Table 1

Environmental information of the five soil pedons

\begin{tabular}{|c|c|c|c|c|c|}
\hline \multirow[t]{2}{*}{ Pedon } & \multirow{2}{*}{$\begin{array}{l}\text { Slope } \\
(\%)\end{array}$} & \multirow{2}{*}{$\begin{array}{l}\text { Elevation } \\
\text { (m) }\end{array}$} & \multirow{2}{*}{$\begin{array}{l}\text { Solum } \\
\text { thickness } \\
(\mathrm{cm})\end{array}$} & \multicolumn{2}{|c|}{ Soil classification } \\
\hline & & & & WRB system ${ }^{a}$ & Soil taxonomy ${ }^{\mathrm{b}}$ \\
\hline \multicolumn{6}{|c|}{ 1st level } \\
\hline $\mathrm{Tt}-1$ & 3 & 80 & 52 & Vertisols & Typic Hapluderts \\
\hline $\mathrm{Tt}-2$ & 2 & 70 & 60 & Vertisols & Typic Hapluderts \\
\hline \multicolumn{6}{|c|}{ 2nd level } \\
\hline $\mathrm{Tt}-3$ & 5 & 65 & 22 & Chernozems & Vertic Hapludolls \\
\hline Tt-4 & 5 & 60 & 50 & Chernozems & Typic Hapludolls \\
\hline \multicolumn{6}{|c|}{ 3rd level } \\
\hline Tt-5 & 2 & 35 & 40 & Arenosols & Typic Udipsamments \\
\hline
\end{tabular}

${ }^{\text {a }}$ ISSS Working Group WRB (1998).

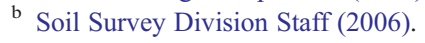


Table 2

Morphological characteristics of the five soil pedons

\begin{tabular}{|c|c|c|c|c|c|c|c|c|}
\hline Horizon & Depth $(\mathrm{cm})$ & Munsell color (moist) & Texture $^{\mathrm{a}}$ & Structure $^{\mathrm{b}}$ & Consistence $^{\mathrm{c}}$ & Crack and stress coatings ${ }^{\mathrm{d}}$ & Roots $^{\mathrm{e}}$ & Boundary ${ }^{f}$ \\
\hline \multicolumn{9}{|l|}{$T t-1$} \\
\hline Ap & $0-15$ & $10 \mathrm{YR} 2 / 2$ & $\mathrm{C}$ & $3 c \& v c$ abk & vfir, vs\&vp & $\mathrm{sf} \& \mathrm{~m} \mathrm{cr}$ & mvf\&f & $\mathrm{cw}$ \\
\hline Bss1 & $15-30$ & $\begin{array}{l}\text { 10YR 3/1 }(80 \%) \\
10 \text { YR 4/6 (20\%) }\end{array}$ & $\mathrm{C}$ & $3 c \& v c$ abk & vfir, vs\&vp & sf\&m cr, m sli & $f v f \& f$ & $\mathrm{cw}$ \\
\hline Bss2 & $30-40$ & $\begin{array}{l}2.5 \text { Y } 3 / 1(90 \%) \\
10 \text { YR 4/6 (10\%) }\end{array}$ & $\mathrm{C}$ & $3 \mathrm{~m}$ abk & vfir, vs\&vp & sf\&m cr, f sli & - & $\mathrm{cw}$ \\
\hline Bss3 & $40-52$ & $2.5 \mathrm{Y} 3 / 1$ & $\mathrm{SC}$ & $2 v f, f \& m$ sbk & mfir, ss\&wp & sf\&m cr, f sli & - & $\mathrm{cw}$ \\
\hline $\mathrm{C}$ & $52-70$ & $5 Y 3 / 2$ & SCL & $2 v f \& f g$ & mfir, vws\&vwp & & & $\mathrm{cw}$ \\
\hline $\mathrm{R}$ & 70 & & & & & & & \\
\hline \multicolumn{9}{|l|}{$T t-2$} \\
\hline Ap & $0-30$ & $\begin{array}{l}5 Y 2.5 / 1(90 \%) \\
5 Y R 3 / 4(10 \%)\end{array}$ & $\mathrm{C}$ & $3 \mathrm{vc}$ abk & vfir, ms\&vp & $\mathrm{sm} \mathrm{cr}$ & svf\&f & $\mathrm{cw}$ \\
\hline Bss1 & $30-40$ & $10 \mathrm{YR} 4 / 1$ & $\mathrm{C}$ & $3 \mathrm{c}$ abk & vfir, vs\&vp & sf cr, f sli & $\mathrm{ff}$ & $\mathrm{cw}$ \\
\hline Bss2 & $40-60$ & $2.5 \mathrm{Y} 4 / 1$ & $\mathrm{C}$ & $3 m \& c$ abk & mfir, ws\&mp & svf\&f cr, f sli & - & gw \\
\hline $\mathrm{C}$ & $60-70$ & $2.5 Y 5 / 1$ & $\mathrm{C}$ & $2 \mathrm{~m} \mathrm{sbk}$ & mfir, ss\&mp & & & \\
\hline \multicolumn{9}{|l|}{$T t-3$} \\
\hline Ap1 & $0-12$ & $\begin{array}{l}2.5 \text { Y } 2.5 / 1(60 \%) \\
7.5 \text { YR 5/6 }(40 \%)\end{array}$ & $\mathrm{C}$ & $3 \mathrm{c}$ abk, $3 \mathrm{f} \& \mathrm{~m} g$ & fir, ss\&sp & sm cr, f sli & $\mathrm{mf} \& \mathrm{~m}$ & cs \\
\hline Ap2 & $12-22$ & $\begin{array}{l}\text { 10YR 3/1 (80\%) } \\
10 \text { YR 5/8 (20\%) }\end{array}$ & $\mathrm{C}$ & $3 c \& v c a b k$ & vfir, ss\&sp & sf cr, f sli & svf\&f & gw \\
\hline $\mathrm{C}$ & $22-33$ & $2.5 \mathrm{Y} 3 / 1$ & SCL & $3 \mathrm{~m} \mathrm{sbk}$ & fir, ss\&mp & - & & aw \\
\hline $\mathrm{R}$ & 33 & & & & & & & \\
\hline \multicolumn{9}{|l|}{$T t-4$} \\
\hline Ap & $0-30$ & 10YR 2/1 & $\mathrm{C}$ & $3 \mathrm{c}$ abk & fir, ms\&vp & - & svf\&f & $\mathrm{cw}$ \\
\hline $\mathrm{Bw}$ & $30-50$ & $2.5 \mathrm{Y} 3 / 1$ & $\mathrm{C}$ & $2 \mathrm{~m} \mathrm{sbk}$ & fir, ss\&sp & - & svf\&f & gw \\
\hline $\mathrm{C}$ & $50-70$ & $2.5 Y 3 / 2$ & $\mathrm{C}$ & $2 \mathrm{~m} \mathrm{sbk}$ & mfir, ss\&mp & - & $f v f \& f$ & $\mathrm{cw}$ \\
\hline $\mathrm{R}$ & 70 & & & & & & & \\
\hline \multicolumn{9}{|l|}{$T t-5$} \\
\hline A & $0-40$ & $2.5 \mathrm{Y} 2.5 / 1$ & S & $2 \mathrm{~m} \& \mathrm{c} \mathrm{sbk}$ & fr, ns\&np & - & $m f \& m$ & gs \\
\hline $\mathrm{C} 1$ & $40-75$ & 10YR 3/2 & S & $1 \mathrm{~m} \mathrm{sbk}$ & $\mathrm{fr}, \mathrm{ns} \& \mathrm{np}$ & - & $f v f \& f$ & ds \\
\hline $\mathrm{C} 2$ & $75-110$ & $2.5 \mathrm{Y} 3 / 2$ & S & 0 & - & - & & ds \\
\hline $\mathrm{C} 3$ & $>110$ & $2.5 \mathrm{Y} 3 / 3$ & S & 0 & - & - & & \\
\hline
\end{tabular}

${ }^{a} \mathrm{C}=$ clay, $\mathrm{S}=$ sand, $\mathrm{SC}=$ sandy clay, $\mathrm{SCL}=$ sandy clay loam.

b $0=$ structureless, 1 = weak, $2=$ moderate, $3=$ strong, $\mathrm{vf}=$ very fine, $\mathrm{f}=$ fine, $\mathrm{m}=$ medium, $\mathrm{c}=$ coarse, $\mathrm{vc}=$ very coarse; $\mathrm{gr}=$ granular, abk = angular blocky, sbk = subangular blocky.

${ }^{c}$ fir $=$ firm, fr = friable, $v$ fir $=$ very firm, mfir $=$ moderate firm; $s=$ sticky, $p=$ plastic, ms = moderate sticky, $m p=$ moderate plastic, $n s=$ non-sticky, $n p=$ non-plastic, $\mathrm{ss}=$ slightly sticky, $\mathrm{sp}=$ slightly plastic, $\mathrm{vs}=$ very sticky, $\mathrm{vp}=$ very plastic, $\mathrm{ws}=$ weak sticky, $\mathrm{wp}=$ weak plastic, vws $=$ very weak sticky.

${ }^{\mathrm{d}} \mathrm{f}=$ few, $\mathrm{s}=$ some, $\mathrm{m}=$ many; $\mathrm{f}=$ fine, $\mathrm{m}=$ medium, $\mathrm{vf}=$ very fine; $\mathrm{cr}=$ crack, sli = slickenside.

${ }^{\mathrm{e}} \mathrm{f}=$ few, $\mathrm{m}=$ many, $\mathrm{s}=$ some; $\mathrm{f}=$ fine, $\mathrm{m}=$ medium, $\mathrm{vf}=$ very fine.

${ }^{\mathrm{f}} \mathrm{a}=$ abrupt, $\mathrm{c}=$ clear, $\mathrm{d}=$ diffuse, $\mathrm{g}=$ gradual; $\mathrm{s}=$ smooth, $\mathrm{w}=$ wave.

taken using criteria of the U.S. Soil Survey Manual (Soil Survey Division Staff, 1993). Soil samples were collected from each horizon of the profiles for physical and chemical analysis.

\subsection{Laboratory analyses}

Soil samples were air-dried and passed through a 2-mm screen. Particle size distribution was determined by the pipette method (Gee and Bauder, 1986). The $\mathrm{pH}$ of air-dried samples $(<2 \mathrm{~mm})$ was determined on a mixture of soil/deionized water (1:1) by glass electrode (McLean, 1982). Organic carbon (OC) content was measured by the Walkley-Black wet oxidation method (Nelson and Sommers, 1982). Carbonate content was determined by the gravimetric method (Nelson, 1982). Cation exchange capacity and exchangeable bases were measured with the ammonium acetate method (pH 7.0) (Rhoades, 1982). Free Fe $\left(\mathrm{Fe}_{\mathrm{d}}\right)$ and $\mathrm{Mn}\left(\mathrm{Mn}_{\mathrm{d}}\right)$ were extracted by the dithionite-citrate-bicarbonate (DCB) method (Mehra and Jackson, 1960). Amorphous $\mathrm{Fe}\left(\mathrm{Fe}_{\mathrm{o}}\right)$ was extracted by $0.2 \mathrm{M}$ ammonium oxalate (pH 3.0) (McKeague and Day, 1966). All the metals in the solution were determined by flame atomic absorption spectrometry (Hitachi Z-8100 type, Japan).

Micromorphology of soil horizons on different terraces from undisturbed samples was described using polarized light microscopy. Descriptive terminology follows Bullock et al. (1985). Major element concentrations were measured on bulk, powdered samples using wavelength-dispersive X-ray fluorescence (XRF) (Spectro Xepos, Germany). The XRF chemical data of five soils were evaluated using a mass-balance approach, following Brimhall et al. $(1988,1991 \mathrm{a}, \mathrm{b})$. The derivation of mass-balance equations and their application to pedogenic processes are discussed in detail by 
Brimhall and Dietrich (1987) and Chadwick et al. (1990). Therefore, for the purpose of this paper, only the most general aspects of the model are discussed, i.e., those dealing with (1) the compaction or dilation that has occurred as a result of soil-forming processes, and (2) long-term constituent gains or losses. X-ray diffraction (XRD) analysis was performed on the oriented $\mathrm{K}$ - and $\mathrm{Mg}$-saturated clay samples. The oriented clays were examined with an X-ray diffractometer (Rigaku D/max-2200/PC type, Japan) and Ni-filtered $\mathrm{Cu}-\mathrm{K} \alpha$ radiation generated at $30 \mathrm{kV}$ and $10 \mathrm{~mA}$. The XRD patterns were recorded ranging from 3 to $60^{\circ}(2 \theta)$ with a scanning speed of $0.5^{\circ}(2 \theta) \mathrm{min}^{-1}$. The identification and semiquantitative determination of the clay minerals were based on the difference of reflection patterns from the $\mathrm{K}$-saturated, $\mathrm{Mg}$-saturated, glycolated, heated, and air-dried samples (Brindley, 1980; Brown and Brindley, 1980).

\section{Results and discussion}

\subsection{Field morphology and micromorphology}

The oldest soils (Tt-1 and Tt-2), which are on the 1st level terrace are similar in soil morphological characteristics (Table 2), including the soil horizon arrangement (A-Bss-C), soil depth (about 50-60 cm), surface cracks and stress coatings. The surface horizon of Tt-1 and Tt-2 soil profiles is characterized by very dark brown to black, clayey texture, strongly developed coarse and very coarse angular blocky structure, very firm, and some fine and medium cracks. The angular blocky structures of surface horizons on the 1st level terrace in the present work are different from some Usterts which have granular-structured surface horizons (Nettleton and Sleeman, 1985). The subsurface horizon, Bss horizon, is characterized by dark gray to very dark gray, clay texture, strong developed medium, coarse and very coarse angular blocky structure, very firm consistence, some fine and medium cracks, and especially some slickenside features. Therefore, the subsurface horizons on the 1st level terrace show typical morphological characteristics of well-drained Vertisols in the tropical and subtropical regions (Soil Survey Division Staff, 2006). Soil micromorphological observations generally support field morphological observations with changes in thin sections that are clearly time- and depth-dependent. Soil fabric, the spatial arrangement of the soil particles and voids, varies consistently with soil age. On the 1st level terrace, the C/Frelated distribution in micromorphology of the subsurface soils is porphyric. However, the dominant pedofeatures are stress coatings in the Bss horizons, whereas the b-fabric is reticulate striated (Fig. 3a). The reticulate striated b-fabric under wetting of the dry clayey soil resulted from the shearing of the clay-sized soil materials such as smectite. Both of the Tt-1 and Tt-2 soils are classified as Vertisols (ISSS Working Group WRB, 1998) and Typic Hapluderts (Soil Survey Division Staff, 2006) (Table 1).

The Tt-3 and Tt-4 soils from the 2 nd level terrace, the younger soils than those from the 1st level terrace, both have thick, very dark gray to black surface horizon with clayey texture, and strong
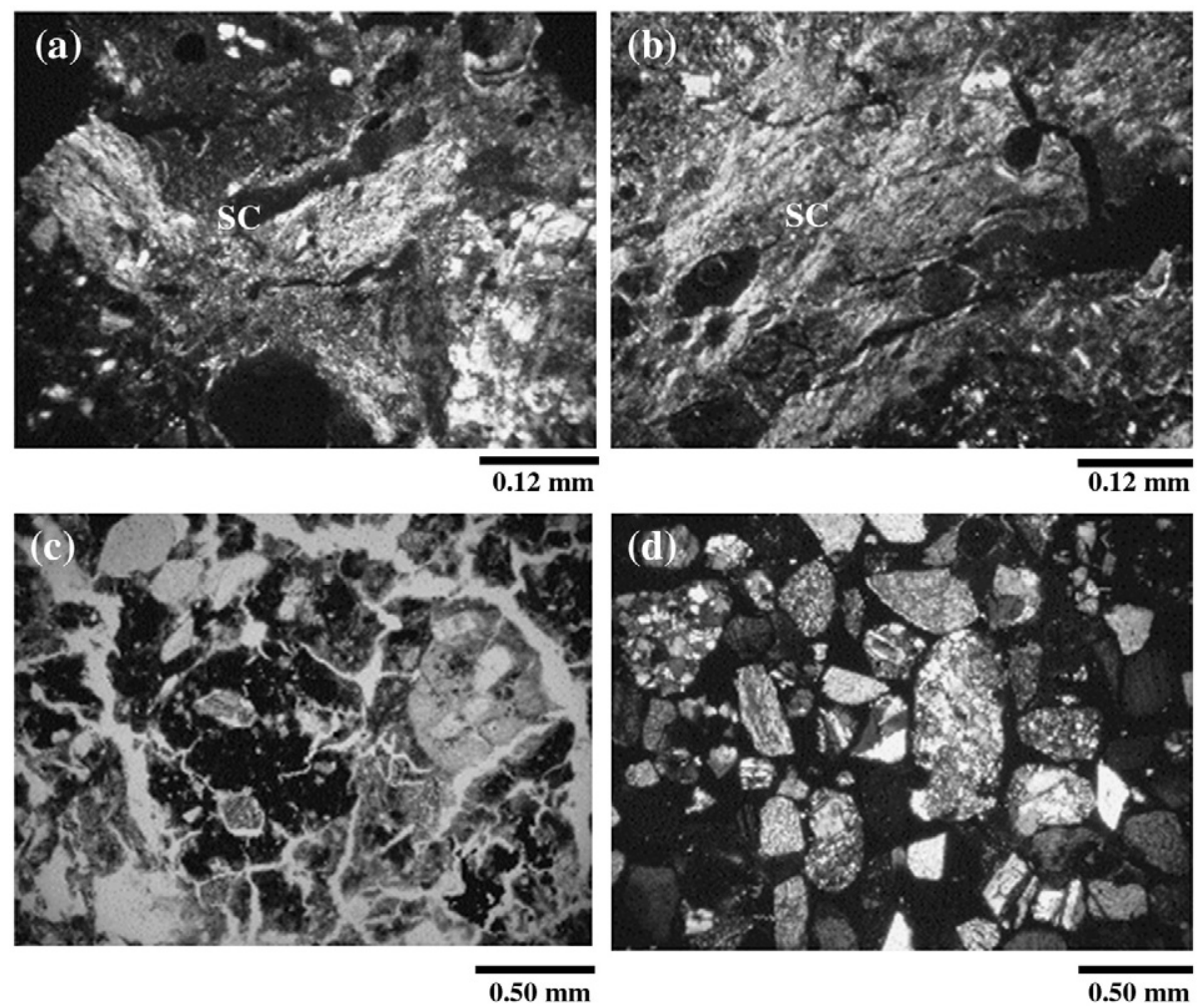

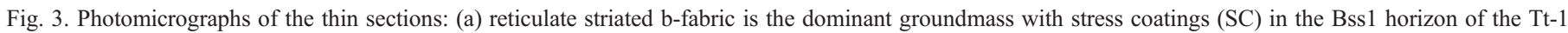

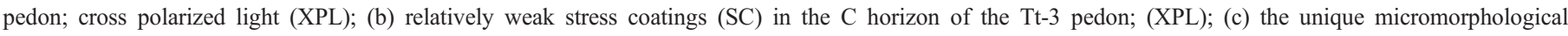

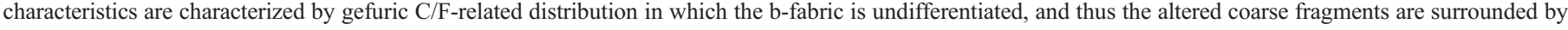

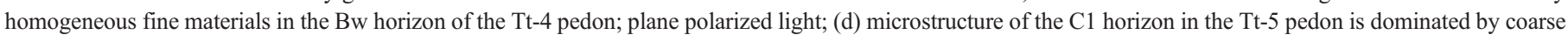
sand grains in which the b-fabric is undifferentiated and the C/F-related distribution is monic; (XPL). 
developed coarse and very coarse angular blocky structure. The $\mathrm{Tt}-3$ soil with relatively high slope is a relatively poorly developed soil and lacks a B horizon, and also has few slickenside features in the surface horizon. The B horizon of Tt- 4 soil is characterized by very dark gray, clayey, and medium developed subangular blocky structure, but no crack or stress coating features appeared. In the observation of the thin sections, stress coatings are also the main pedofeatures of the soils on the 2nd level terrace (Fig. 3b); however, the degree of stressing is lower than that on the 1st level terrace. Regarding the swelling-shrinkage pedoturbation of clay materials, the soils on the 2nd level terrace also have evidence of plasma modification like the Vertisols on the 1st level terrace. However, they differ from the typical Vertisols in failing to crack sufficiently in having low amounts of swelling-type clay to meet the criteria of slickensides for Vertisols. Additionally, the unique micromorphological characteristics of the soils on the 2nd level terrace are characterized by gefuric $\mathrm{C} / \mathrm{F}$-related distribution in which the b-fabric is undifferentiated, and thus the altered coarse fragments are surrounded by homogeneous fine materials (Fig. 3c). Both of the Tt-3 and Tt-4 soils are classified as Chernozems based on the WRB system (ISSS Working Group WRB, 1998); however, the Tt-3 soil is classified as Vertic Hapludolls and Tt-4 soil is classified as Typic Hapludolls based on the Keys to Soil Taxonomy (Soil Survey Division Staff, 2006). The Tt-5 soil, the youngest soil on the 3rd level terrace, is characterized by sandy textures through the soil profile and lacks a $\mathrm{B}$ horizon. The microstructure of the $\mathrm{C} 1$ horizon is dominated by coarse sand grains in which the $b$-fabric is undifferentiated and the $\mathrm{C} /$ F-related distribution is monic (Fig. 3d). No coatings surrounded the grains. Additionally, these grains with a wide range of sizes are generally separated. No clear pedofeatures are found in the soils on the 3 rd level terrace. The Tt-5 soil is classified as Arenosols in the WRB system (ISSS Working Group WRB, 1998) and Typic Udipsamments in the U.S. system (Soil Survey Division Staff, 2006).

Soil morphological properties show only a few trends with age. Overall, the soil textures are clayey (clay $\%>35 \%$ ) on all diagnostic horizons of all pedons except for the Tt-5 pedon (clay $\%$ $<5 \%$ ). Strongly developed angular blocky structure is more common in higher terrace soils, which may be a function of the generally higher clay content in these soils. However, pressure faces and slickensides are common in the higher terrace soils, which may be qualified as Vertisols. Muhs (2001) thought that soils or their remnants are redder with increasing terrace age. Nevertheless, the soil colors of this study show no change with terrace age. According to the study results in southwestern Oregon, Bockheim et al. (1996) suggested that some morphological properties increase with relative age, including depth to $\mathrm{C}$ horizon, solum thickness, depth to maximum clay content, and thickness of the clay-enriched zone. In this study, including depth to $\mathrm{C}$ horizon, solum thickness, and thickness of the clay-enriched zone show increases with relative terrace age.

\subsection{Physical and chemical properties}

The bulk density $(\mathrm{Bd})$ is similar within the five soils, on average greater than $1.5 \mathrm{Mg} \mathrm{m}^{-3}$ (except Tt-5 pedon) (Table 3).
The Bd indicates that these soils are hardened and have strong developed soil structures (Table 2). High clay contents were found in all soils except for Tt-5 soil. In general, the clay content $>35 \%$ in all soil horizons except for $\mathrm{C}$ horizons. The highest clay content (70.5\%) was found in the Ap horizon of Tt-2 soil, and this was attributed to the frequent tillage and deep plowing for lowland rice, which resulted in higher soil weathering and clay disturbance between horizons. In the sand-sized classes, fine $(0.25-0.10 \mathrm{~mm})$ and very fine $(0.10-0.05 \mathrm{~mm})$ sands are dominant in soils on the highest, oldest terrace (1st level). On the relatively young terrace (2nd level), fine and very fine sands are still dominant in Tt-3 soil, but very coarse $(2.0-1.0 \mathrm{~mm})$, medium $(0.5-0.25 \mathrm{~mm})$, fine and very fine sands are dominant in Tt-4 soil. On the lowest terrace, very coarse and coarse $(1.0-0.5 \mathrm{~mm})$ sands are dominant.

For the particle size distribution, the results of Merritts et al. (1991) in northern California indicated that successively older soil has markedly lower amounts of sand, and correspondingly greater amounts of silt and clay. Bockheim et al. (1996) also suggested that profile sums and maximum concentrations of silt and clay increased with time. The results of this study are not consistent with the conclusions of Merritts et al. (1991) and Bockheim et al. (1996). The clay contents in the first and second

Table 3

Bulk densities and particle size distributions of the five soil pedons

\begin{tabular}{|c|c|c|c|c|c|c|c|c|c|c|}
\hline \multicolumn{2}{|c|}{ Horizon Depth } & \multirow{3}{*}{$\begin{array}{l}\mathrm{Bd}^{\mathrm{a}} \\
\frac{\mathrm{Mg}}{\mathrm{m}^{-3}}\end{array}$} & \multicolumn{3}{|c|}{ Texture } & \multicolumn{5}{|c|}{ Sand-sized classes ${ }^{b}$} \\
\hline & & & Sand & Silt & Clay & $\mathrm{VC}$ & $\mathrm{C}$ & M & $\mathrm{F}$ & VF \\
\hline & $\mathrm{cm}$ & & \multicolumn{3}{|l|}{$\%$} & \multicolumn{5}{|l|}{$\%$} \\
\hline \multicolumn{11}{|l|}{$T t-1$} \\
\hline Ap & $0-15$ & 1.9 & 17.2 & 24.0 & 58.8 & 1.0 & 0.9 & 2.0 & 6.6 & 6.8 \\
\hline Bss1 & $15-30$ & 1.7 & 26.7 & 16.8 & 56.5 & 1.9 & 1.2 & 3.8 & 12 & 7.5 \\
\hline Bss2 & $30-40$ & 1.5 & 29.4 & 19.3 & 51.3 & 1.0 & 1.7 & 4.4 & 14 & 8.2 \\
\hline Bss3 & $40-52$ & 1.9 & 54.2 & 10.6 & 35.2 & 3.5 & 6.7 & 9.5 & 18 & 16 \\
\hline $\mathrm{C}$ & $52-70$ & 1.8 & 62.2 & 16.3 & 21.5 & 4.6 & 7.0 & 12 & 24 & 15 \\
\hline \multicolumn{11}{|l|}{$T t-2$} \\
\hline Ap & $0-30$ & 1.7 & 13.5 & 16.0 & 70.5 & 0.5 & 0.8 & 1.3 & 5.3 & 5.7 \\
\hline Bss 1 & $30-40$ & 1.7 & 35.7 & 22.4 & 41.9 & 1.0 & 1.4 & 2.2 & 18 & 14 \\
\hline Bss2 & $40-60$ & 1.6 & 21.8 & 13.9 & 64.3 & 1.6 & 2.4 & 3.4 & 8.2 & 6.2 \\
\hline $\mathrm{C}$ & $>60$ & 1.6 & 44.8 & 17.8 & 37.4 & 3.5 & 5.7 & 7.5 & 17 & 11 \\
\hline \multicolumn{11}{|l|}{$T t-3$} \\
\hline Ap1 & $0-12$ & 1.7 & 27.9 & 16.0 & 56.1 & 3.0 & 2.3 & 4.6 & 9.6 & 8.4 \\
\hline Ap2 & $12-22$ & 1.7 & 32.4 & 23.0 & 44.6 & 2.9 & 1.7 & 3.4 & 10 & 14 \\
\hline $\mathrm{C}$ & $22-33$ & 1.6 & 63.7 & 16.6 & 19.7 & 3.0 & 5.5 & 3.5 & 20 & 32 \\
\hline \multicolumn{11}{|l|}{$T t-4$} \\
\hline Ap & $0-30$ & 1.6 & 28.1 & 11.1 & 60.8 & 9.1 & 1.7 & 7.1 & 6.7 & 3.6 \\
\hline $\mathrm{Bw}$ & $30-50$ & 1.5 & 25.3 & 13.6 & 61.1 & 7.7 & 1.7 & 6.0 & 6.4 & 3.5 \\
\hline $\mathrm{C}$ & $50-70$ & 1.5 & 22.8 & 22.4 & 54.8 & 7.7 & 0.9 & 8.1 & 2.3 & 3.8 \\
\hline \multicolumn{11}{|l|}{$T t-5$} \\
\hline A & $0-40$ & 1.5 & 96.1 & 0.51 & 3.42 & 27 & 45 & 11.4 & 9.0 & 3.5 \\
\hline $\mathrm{C} 1$ & $40-75$ & 1.6 & 95.6 & 0.06 & 4.38 & 27 & 52 & 12 & 2.4 & 2.2 \\
\hline $\mathrm{C} 2$ & $75-110$ & 1.4 & 93.8 & 1.11 & 5.13 & 50 & 33 & 8.1 & 2.5 & 1.0 \\
\hline C3 & $>110$ & 1.4 & 94.6 & 0.83 & 4.56 & 55 & 25 & 12 & 1.9 & 1.8 \\
\hline
\end{tabular}


levels are similar, and do not increase with time. We thought that the soil age of these two terraces was close (the 1st level is about 9-10 ka and the 2nd level is about 5-6 ka), the clay content showed no significant increase with time. The result of sand-sized classes indicated that the degree of sand grains weathering increased with terrace age, that is, the sand size was finer in the older terrace in contrast in the younger terrace.

The $\mathrm{pH}\left(\mathrm{H}_{2} \mathrm{O}\right)$ of representative soils on the terraces increased with increasing profile depth, ranging from strongly acid (5.4) in organic-rich surface mineral horizons to neutral (7.1) in the subsoil (Table 4); however, the $\mathrm{pH}$ shows a little increase with terrace age. Soil organic carbon (OC) is greatest in the surface mineral horizon, and then decreases with further depth. The accumulated mass of OC has a somewhat time-dependent trend, which is higher in upper (older) terraces, and lower in lower (younger) terrace. Cation exchange capacity (CEC) does not follow the same trend as organic carbon. With the exception of Tt-5 soil, CEC increases in the $\mathrm{B}$ horizon or subsoil, and then decreases in the $\mathrm{C}$ horizon. Both organic carbon and $\mathrm{CEC}$ follow the same trend as $\mathrm{pH}$, the values increasing with terrace age. The $100 \%$ of base saturation (BS) indicated that $\mathrm{Ca}$ is the dominant exchangeable base in those soil or horizons. The BS of Tt-5 soil is relatively low, also has shallow solum thickness and great sand content. The change of BS between the 1st level and the 2nd level is not clear, but it

Table 4

Selected chemical properties of the five soil pedons

\begin{tabular}{|c|c|c|c|c|c|c|c|c|c|}
\hline \multirow[t]{2}{*}{ Horizon } & Depth & $\mathrm{pH}$ & $\mathrm{OC}$ & CEC & BSP & $\mathrm{CaCO}_{3}$ & $\mathrm{Fe}_{\mathrm{d}}$ & $\mathrm{Mn}_{\mathrm{d}} \mathrm{Fe}_{\mathrm{o}}$ & $\mathrm{Fe}_{t}$ \\
\hline & $\mathrm{cm}$ & & $\mathrm{g} / \mathrm{kg}$ & $\begin{array}{l}\mathrm{cmol} \\
(+) / \mathrm{kg}\end{array}$ & $\%$ & & $\mathrm{~g} / \mathrm{kg}$ & & \\
\hline
\end{tabular}

\section{$T t-1$}

$\begin{array}{lllllll}\text { Ap } & 0-15 & 5.4 & 37.3 & 35.4 & 100 & 0.33\end{array}$

$\begin{array}{llllllll}\text { Bss1 } & 15-30 & 6.7 & 24.6 & 41.9 & 57 & 0.35\end{array}$

$\begin{array}{lllllll}\text { Bss2 } & 30-40 & 7.0 & 13.0 & 44.0 & 67 & 0.89\end{array}$

$\begin{array}{lllllll}\text { Bss3 } & 40-52 & 7.1 & 10.8 & 43.6 & 63 & 0.89\end{array}$

$\begin{array}{lllllll}\text { C } & 52-70 & 7.1 & 9.70 & 35.7 & 76 & 1.19\end{array}$

$T t-2$

$\begin{array}{lllllll}\text { Ap } & 0-30 & 6.3 & 21.6 & 38.8 & 100 & 0.80\end{array}$

$\begin{array}{lllllll}\text { Bss1 } & 30-40 & 6.8 & 9.31 & 46.9 & 90 & 0.81\end{array}$

$\begin{array}{lllllll}\text { Bss2 } & 40-60 & 6.9 & 8.90 & 53.0 & 85 & 0.80\end{array}$

$\begin{array}{lllllll}\text { C } & 60-70 & 7.0 & 8.23 & 35.7 & 100 & 1.23\end{array}$

$T t-3$

$\begin{array}{lllllll}\text { Ap1 } & 0-12 & 5.5 & 26.5 & 19.2 & 100 & 0.44\end{array}$

$\begin{array}{lllllll}\text { Ap2 } & 12-22 & 6.0 & 24.6 & 30.8 & 100 & 0.81\end{array}$

$\begin{array}{lllllll}\text { C } & 22-33 & 6.6 & 8.21 & 22.8 & 100 & 0.98\end{array}$

$T t-4$

$\begin{array}{lllllll}\text { Ap } & 0-30 & 6.0 & 16.4 & 29.4 & 100 & 0.48\end{array}$

$\begin{array}{lllllll}\mathrm{Bw} & 30-50 & 6.9 & 8.87 & 48.4 & 66 & 1.29\end{array}$

$\begin{array}{lllllll}\text { C } & 50-70 & 7.0 & 8.88 & 50.9 & 39 & 1.24\end{array}$

Tt-5

\begin{tabular}{lllllllllll} 
A & $0-40$ & 5.9 & 21.6 & 5.55 & 39 & 0.80 & 2.20 & 0.20 & 1.41 & 61.1 \\
$\mathrm{C} 1$ & $40-75$ & 6.0 & 9.68 & 3.98 & 31 & 0.80 & 1.51 & 0.11 & 1.03 & 70.5 \\
$\mathrm{C} 2$ & $75-110$ & 6.4 & 7.11 & 4.83 & 40 & 0.81 & 1.71 & 0.14 & 0.99 & 64.8 \\
$\mathrm{C} 3$ & $>110$ & 6.7 & 7.12 & 4.27 & 80 & 0.80 & 1.91 & 0.16 & 1.01 & 79.9 \\
\hline
\end{tabular}

Abbreviations: $\mathrm{OC}=$ organic carbon; $\mathrm{CEC}=$ cation exchange capacity; $\mathrm{BSP}=$ base saturation percentage; $\mathrm{Fe}_{\mathrm{d}}, \mathrm{Mn}_{\mathrm{d}}=\mathrm{DCB}$-extractable $\mathrm{Fe}, \mathrm{Mn} ; \mathrm{Fe}_{\mathrm{o}}=$ oxalateextractable $\mathrm{Fe} ; \mathrm{Fe}_{\mathrm{t}}=$ total $\mathrm{Fe}$ content.
Table 5

Clay mineral composition of the five soil pedons

\begin{tabular}{|c|c|c|c|c|c|c|c|}
\hline Horizon & Depth $(\mathrm{cm})$ & Chlorite & Smectite & Mica & Kaolinite & Gibbsite & Quartz \\
\hline \multicolumn{8}{|l|}{$T t-1$} \\
\hline Ap & $0-15$ & ++ & + & ++ & ++ & + & ++ \\
\hline Bss1 & $15-30$ & ++ & ++ & ++ & ++ & ++ & + \\
\hline Bss2 & $30-40$ & ++ & ++ & ++ & ++ & + & ++ \\
\hline Bss3 & $40-52$ & ++ & ++ & ++ & + & + & + \\
\hline $\mathrm{C}$ & $52-70$ & ++ & + & + & + & + & + \\
\hline \multicolumn{8}{|l|}{$T t-2$} \\
\hline Ap & $0-30$ & ++ & + & ++ & ++ & ++ & + \\
\hline Bss1 & $30-40$ & ++ & + & ++ & ++ & + & ++ \\
\hline Bss2 & $40-60$ & ++ & + & ++ & + & + & + \\
\hline $\mathrm{C}$ & $>60$ & + & - & ++ & + & + & + \\
\hline \multicolumn{8}{|l|}{$T t-3$} \\
\hline Ap1 & $0-12$ & ++ & ++ & ++ & + & + & + \\
\hline Ap2 & $12-22$ & ++ & + & ++ & + & + & + \\
\hline $\mathrm{C}$ & $22-33$ & ++ & + & ++ & + & + & + \\
\hline \multicolumn{8}{|l|}{$T t-4$} \\
\hline Ap & $0-30$ & ++ & + & ++ & + & + & + \\
\hline $\mathrm{Bw}$ & $30-50$ & ++ & + & ++ & ++ & + & + \\
\hline $\mathrm{C}$ & $50-70$ & ++ & - & ++ & + & + & + \\
\hline \multicolumn{8}{|l|}{$T t-5$} \\
\hline A & $0-40$ & ++ & - & + & + & + & ++ \\
\hline $\mathrm{C} 1$ & $40-75$ & ++ & - & + & + & + & ++ \\
\hline $\mathrm{C} 2$ & $75-110$ & ++ & - & + & + & - & + \\
\hline $\mathrm{C} 3$ & $>110$ & +++ & - & + & + & - & + \\
\hline
\end{tabular}

$+=<10 \% ;++=10-25 \% ;+++=25-50 \%$.

decreases between the second level and third level. With the exception of Tt-5 soil, $\mathrm{CaCO}_{3}$ content is lower in surface horizons, increases in the subsoil horizon, and then is greatest in the $\mathrm{C}$ horizon. The greatest content of $\mathrm{CaCO}_{3}$ was found in $\mathrm{Tt}-4$ soil. The depth change of the soil $\mathrm{pH}$ shows a little increase with terrace age, and the $\mathrm{CaCO}_{3}$ content shows no trend with age.

The distributions of $\mathrm{Fe}_{\mathrm{d}}$ and $\mathrm{Fe}_{\mathrm{o}}$ with soil depth follow the same trend as organic carbon. The contents of $\mathrm{Fe}_{\mathrm{d}}$ and $\mathrm{Fe}_{\mathrm{o}}$ are higher in the 1st level and the 2nd level terrace, but much lower in the 3rd level. This result is similar to that reported by Bockheim et al. (1996), which indicated that the maximum amounts of $\mathrm{Fe}_{\mathrm{d}}$ and the proportion of the crystalline forms of $\mathrm{Fe}$ increase with time in soils near the Cape Blanco region. The $\mathrm{Mn}_{\mathrm{d}}$ concentration increases from the surface soil to subsoil, and then decreases with the following depth. The $\mathrm{Mn}_{\mathrm{d}}$ content is higher in the upper terrace and much lower in the lower terrace. The total $\mathrm{Fe}\left(\mathrm{Fe}_{t}\right)$ content measured by XRF is greatest in the subsoil horizon. The trend of $\mathrm{Fe}_{\mathrm{t}}$ with time is in contrast with other soil properties, it decreases with time. Relatively low amount of $\mathrm{Fe}_{\mathrm{t}}$ is found in the upper terrace (1st level), gradually increases in the intermediate terrace (2nd level), and the lower terrace ( $3 \mathrm{rd}$ level) has the relative highest $\mathrm{Fe}_{\mathrm{t}}$ content. We estimated that a lot of $\mathrm{Fe}$ in the upper terrace was weathered from the soil silicate minerals and lost from the solum, which reduced the amount of $\mathrm{Fe}_{\mathrm{t}}$. In contrast, comparative lower effect of soil silicate weathering and lower leaching has relatively enhanced the $\mathrm{Fe}_{\mathrm{t}}$ amounts in the lower terrace.

Table 5 shows the clay mineral composition of the five soil pedons. Based on X-ray diffraction analysis of the clay-size 


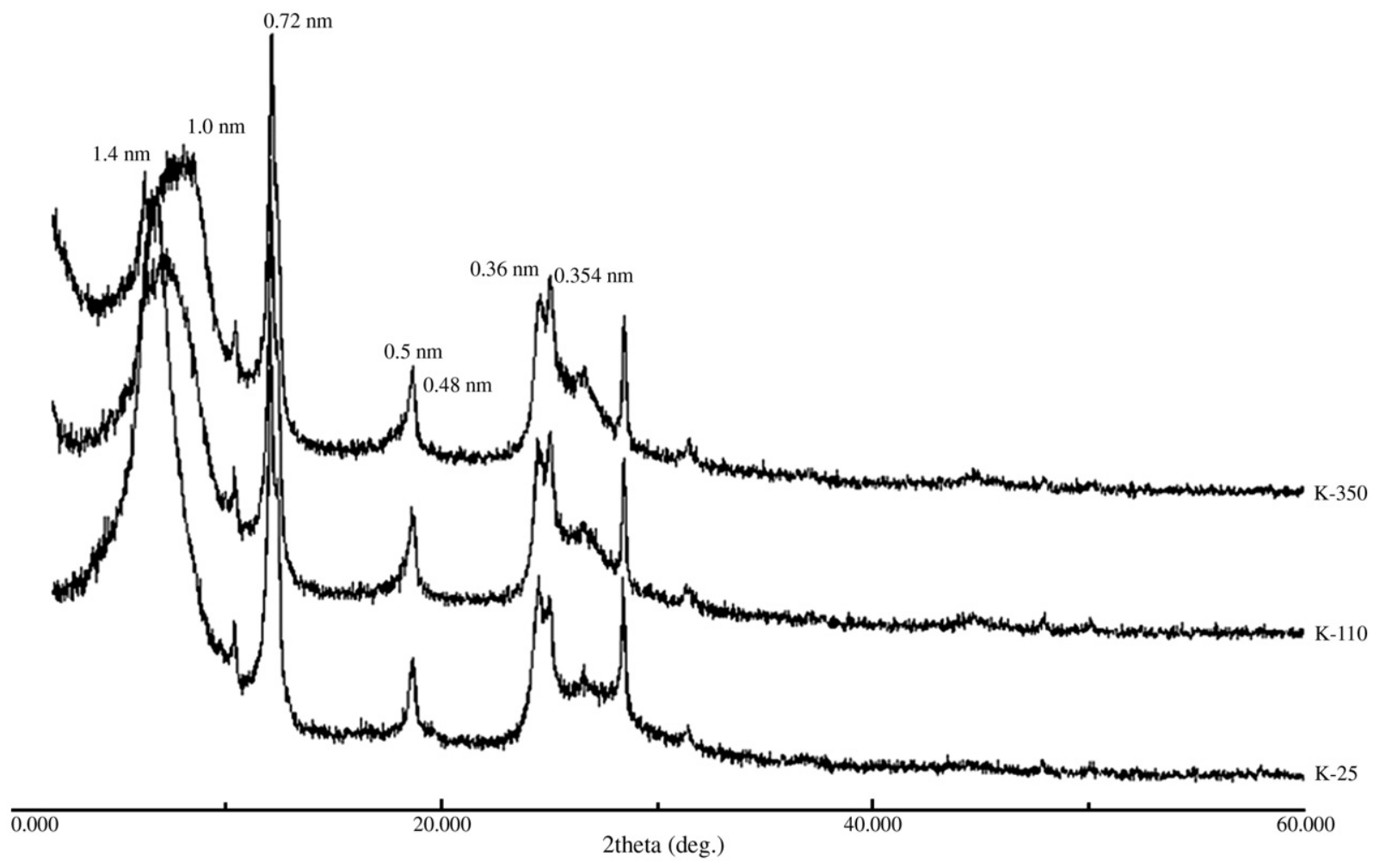

Fig. 4. XRD patterns of K-saturated $\left(25-350^{\circ} \mathrm{C}\right)$ treatments of the clay fraction in the Bss 2 horizon of the Tt-1 pedon.

fraction $(<2 \mu \mathrm{m})$, soils on all terraces have a mixed clay mineralogy (Fig. 4). Chlorite, gibbsite and quartz minerals show no considerable change within the three terrace levels. The abundance of mica is similar in the upper and intermediate terraces, but decreases in the lower terrace. Smectite and kaolinite are relatively abundant in the upper terrace, but those clay minerals are lower in the intermediate terrace. Smectite is detectable in the 1st and 2nd terraces (Fig. 5), but not in the 3rd terrace. The higher CEC content in both upper and intermediate terraces was attributed to the smectite. Bockheim et al. (1996) suggested that soils on younger terraces $(<100 \mathrm{ka})$ have a mixed mineralogy, but soils on the older terraces $(>125 \mathrm{ka})$ are siliceous, containing dominantly quartz. The soil age of this study is less than $10 \mathrm{ka}$, and the clay mineralogy show few changes among the different terraces, especially between the 1st and 2 nd terraces. In comparison with the older and intermediate terraces, the clay mineralogy of the younger (3rd) terrace is different, especially the relatively lower content of smectite, mica, kaolinite and gibbsite.

\subsection{Mass-balance calculations}

Evaluating profile and horizontal uniformity is critical in studies using mass-balance equations. Because $\mathrm{Ti}$ and $\mathrm{Zr}$ are relatively

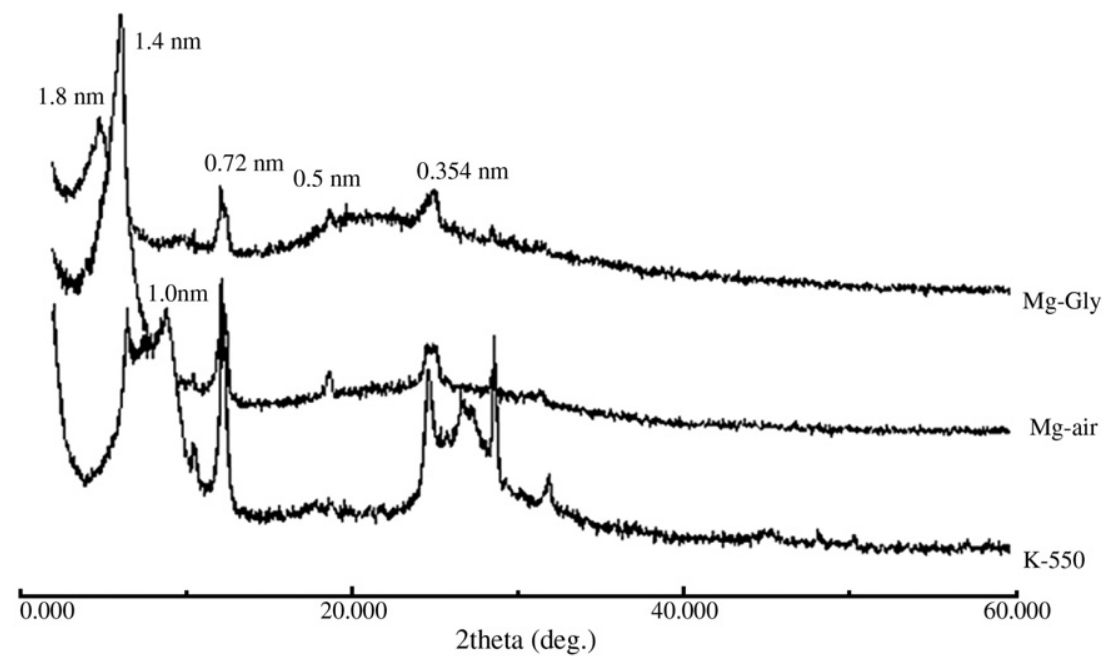

Fig. 5. XRD patterns of Mg-saturated and K-saturated $\left(550^{\circ} \mathrm{C}\right)$ treatments of the clay fraction in the Bss 2 horizon of the Tt-1 pedon. 
Clay-free Sand \%
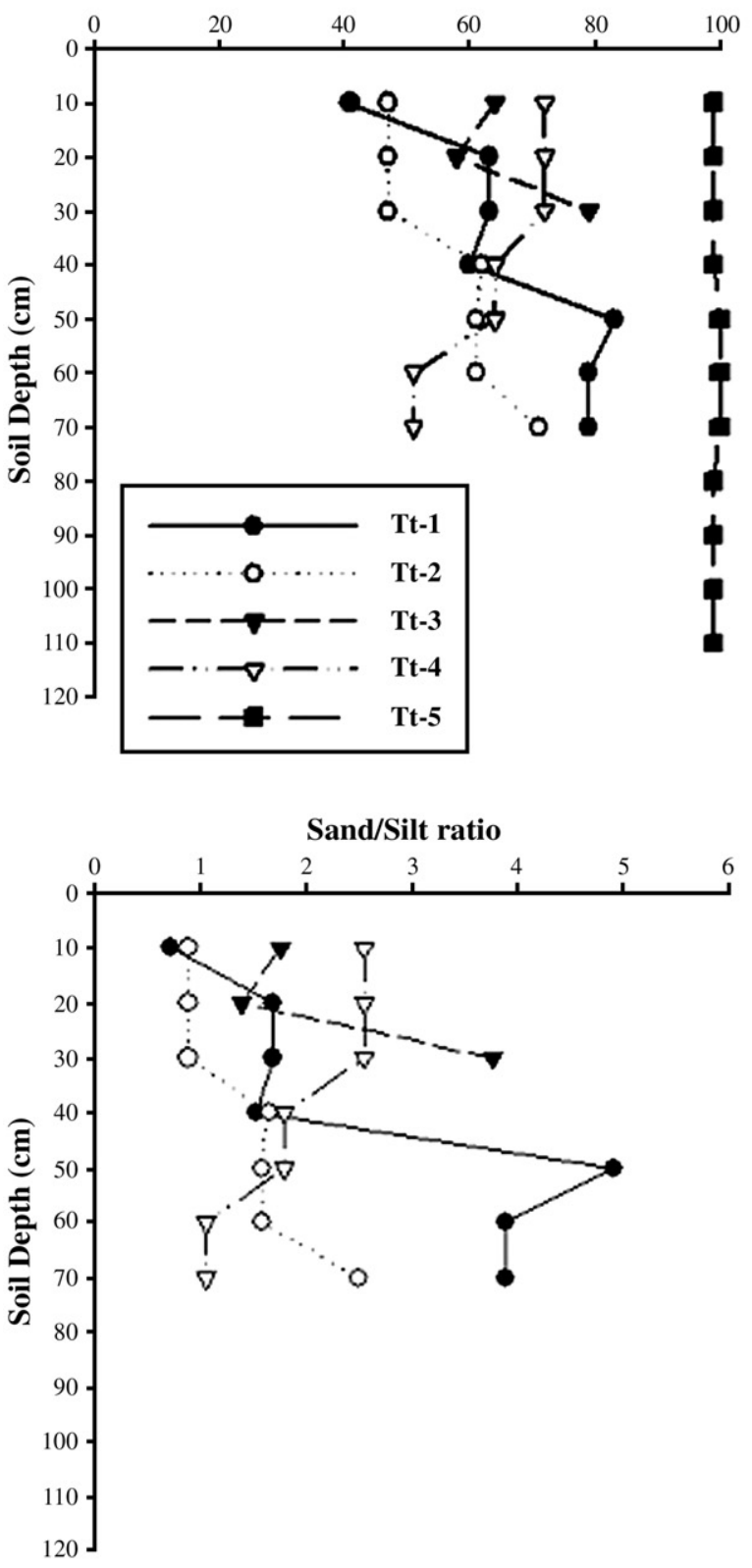

100

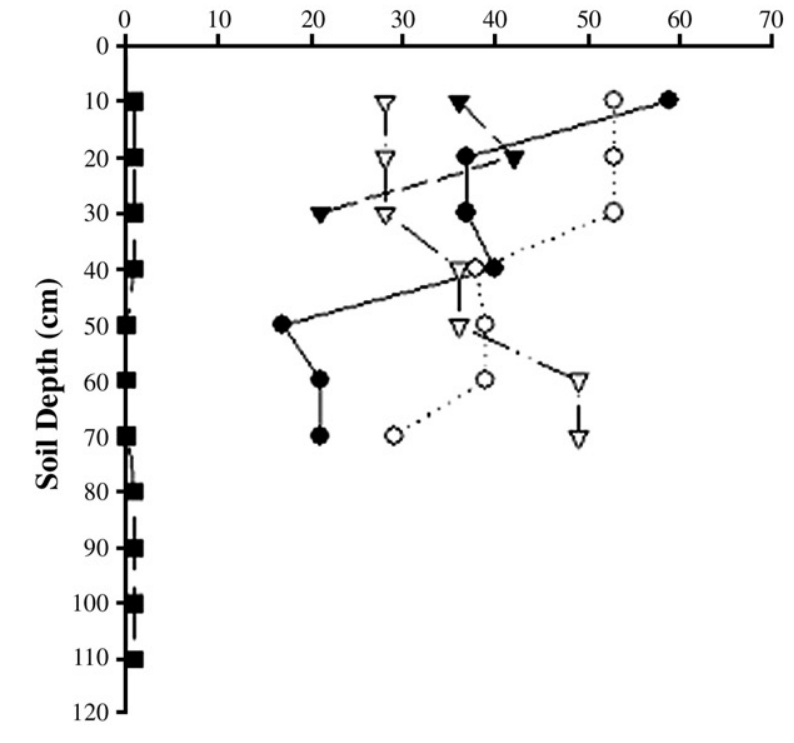

Fig. 6. Depth trends of the stable index constituent Ti, clay-free sand and silt, and sand/silt ratio for the assessment of parent material uniformity.

immobile and do not typically weather they are ideal constitutes for assessing lithological discontinuities (Smeck and Wilding, 1980). Schaetzl (1998) summarized that some parameters can be successfully used to detect lithological discontinuities (LDs) in soils, and suggested that clay-free particle size distributions are the most useful criteria. The results of Tsai and Chen (2000) also indicated that clay-free particle size distributions (Cf-PSDs), sand/ silt ratios, and uniformity value (UV) indices are the most useful parameters in identifying the LDs. Methods to evaluate uniformity include observations of geomorphology, soil horizonation, and spatial structure of geological structure; estimates of sand fractions on a clay-free basis; and $\mathrm{Zr} / \mathrm{Ti}$ ratios of sand and silt-sized particles (Busacca and Singer, 1989; Driese et al., 2000; Karathanasis and Macneal, 1994; Langley-Turnbaugh and Bockheim, 1998; Milnes and Fitzpatrick, 1989; Oh and Richter, 2005; Smeck and Wilding, 1980; Sommer and Stahr, 1996; Stolt et al., 1993; West et al., 1988).

Fig. 6 shows the depth trend of element Ti\%, clay-free sand and silt and sand/silt ratio for assessment of parent material uniformity. The zircon content of the five pedons is lower than the detection limit of X-ray fluorescence, and thus the depth trend of $\mathrm{Zr}$ is excluded. The sand/silt ratios of Tt- 5 soil are much higher than those of the other soils because of the much lower silt content in Tt-5 soil. For this reason, the depth trend of sand/ silt ratio of Tt-5 soil does not show in Fig. 6. Titanium displays a nearly uniform depth distribution and does not vary much in five soils. The depth trends of clay-free sand and silt and sand/ silt ratio of Tt-2 and Tt-4 soils show uniform distribution through the soil profiles, and indicate that the LDs do not exit in 
either soil. In contrast, the depth trends of Tt-1 soil indicate LDs exit in the soil. The morphological attributes, including the clear differences in soil texture and the structures between Bss2 and Bss3 horizons, also support that LDs exit in Tt-1 soil. From the depth trend of clay-free sand and silt, there are no LDs in Tt-5 soil. Tt-3 soil is too shallow to identify the parent material uniformity. From the results described above, we concluded that $\mathrm{Ti}$ is residually enriched in all soils and appears to be the best index element. With the exception of Tt-1 and Tt-3 soils, Tt-2, $\mathrm{Tt}-4$ and Tt- 5 soils were selected for the assessment of gains and losses of major elements using Ti as immobile element.

In Tt-2 soil, strain calculations detect net dilation (positive strain value) for all horizons (Table 6). Greatest dilation occurred near the soil surface, where incorporation of organic matter, structure development, and formation of soil pores are maximal, as indicated by Nieuwenhuyse and Van Breemen (1997). However, because there is no relationship between organic matter inputs and zone of dilation, Nordt et al. (2004) suggested that positive strain in the A horizons of Vertisols likely results from a combination of crack infillings in the upper profile and incomplete collapse after swelling. The macroelements, including $\mathrm{K}, \mathrm{Fe}, \mathrm{Al}$, and $\mathrm{Si}$ reveal gains of $22-28 \%$ (mean value) and clay reveals gains of $123 \%$ (mean value) in this study. The greatest gain occurred in the Ap horizon. In contrast, $\mathrm{Ca}$ and $\mathrm{Mg}$ have great losses in the Ap horizon (the mean value of $-18 \%$ for $\mathrm{Ca}$ and $-0.1 \%$ for $\mathrm{Mg}$ ), and this would be attributed to the acidification processes during pedogenic processes from the parent materials to the soils.

Net dilation also occurred in the Ap horizon of Tt- 4 soil, but there is no dilation or collapse in the Bt horizons because of the little change of strain. The mean values show that only $\mathrm{K}, \mathrm{Fe}$ and clay have net gains in the Tt-4 soil, but the gains are much lower than in the $\mathrm{Tt}-2$ soil. The losses of $\mathrm{Ca}$ and $\mathrm{Mg}$ are higher than $30 \%$, Al less than $6 \%$, and Si less than $1 \%$. Strain values are slightly negative throughout the $\mathrm{Tt}-5$ profile, indicating collapse of up to $90 \%$ of the volume occupied by the parent material. Potassium has gains greater than $40 \%$, which are due to the chemical weathering of the parent material. Because of the coarse-textured soil, illuviation easily occurred in Tt- 5 soil and resulted in the notable losses of $\mathrm{Ca}, \mathrm{Fe}$, and clay. Aluminum and $\mathrm{Si}$ also have little gains in $\mathrm{Tt}-5$ soil. Additionally, $\mathrm{Mg}$ is not detected throughout the profile.

Positive strain values, indicating dilation, occurred in the upper and intermediate terraces. The mean strain value of the 1 st level is twice as high as that of the 2nd level. Slightly negative strain values, indicating collapse, only occurred in the lower terrace. The dominant processes in the intermediate and lower terrace identified with mass-balance analysis include loss of bases $(\mathrm{Ca}$ and $\mathrm{Mg}), \mathrm{Fe}$, and clay with time. This is probably due to the considerable soil leaching that occurred. The relative abundance of kaolinite and gibbsite that occurred in the higher level of terrace also has higher net gains of $\mathrm{Fe}, \mathrm{Al}$, and $\mathrm{Si}$, and then decreases in the lower and younger levels of terrace. The gains of clay in the higher level of terrace are notable, a combination of crack infillings in the surface horizon of profile and incomplete collapse after swelling was estimated as the formation mechanism. The highest gains of $\mathrm{K}$ are found in the
Table 6

Gains and losses of major elements and clay in three selected soil pedons

\begin{tabular}{|c|c|c|c|c|c|c|c|c|c|}
\hline \multirow[t]{2}{*}{ Horizon } & Depth & Strain & $\mathrm{K}$ & $\mathrm{Ca}$ & $\mathrm{Mg}$ & $\mathrm{Fe}$ & $\mathrm{Al}$ & $\mathrm{Si}$ & Clay \\
\hline & \multicolumn{2}{|l|}{$\mathrm{cm}$} & \multicolumn{7}{|l|}{$\%$} \\
\hline \multicolumn{10}{|l|}{$T t-2$} \\
\hline Ap & $0-30$ & 0.33 & 34 & -34 & -20 & 38 & 29 & 40 & 168 \\
\hline Bt1 & $30-40$ & 0.17 & 7 & 10 & 29 & 22 & 34 & 19 & 41 \\
\hline $\mathrm{Bt} 2$ & $40-60$ & 0.13 & 29 & -9 & 16 & 7 & 4 & 15 & 96 \\
\hline \multirow[t]{2}{*}{$\mathrm{C}$} & $60-70$ & 0.00 & 0 & 0 & 0 & 0 & 0 & 0 & 0 \\
\hline & Mean $^{a}$ & 0.24 & 28 & -18 & -0.1 & 25 & 22 & 28 & 123 \\
\hline \multicolumn{10}{|l|}{$T t-4$} \\
\hline Ap & $0-30$ & 0.19 & 15 & -40 & -63 & -2 & -6 & 6 & 24 \\
\hline $\mathrm{Bt}$ & $30-50$ & 0.00 & 0 & -25 & -24 & 4 & -6 & -9 & 11 \\
\hline \multirow[t]{2}{*}{$\mathrm{C}$} & $50-70$ & 0.00 & 0 & 0 & 0 & 0 & 0 & 0 & 0 \\
\hline & Mean $^{+}$ & 0.12 & 9 & -34 & -47 & 0.3 & -6 & -0.3 & 19 \\
\hline \multicolumn{10}{|l|}{$T t-5$} \\
\hline A & $0-40$ & -0.09 & 60 & -31 & - & -26 & 3 & -1 & -32 \\
\hline $\mathrm{C} 1$ & $40-75$ & -0.04 & 19 & -3 & - & -3 & 25 & 4 & -72 \\
\hline $\mathrm{C} 2$ & $75-110$ & -0.09 & 60 & 13 & - & -21 & -4 & -3 & 22 \\
\hline \multirow[t]{2}{*}{$\mathrm{C} 3$} & $>110$ & 0.00 & 0 & 0 & - & 0 & 0 & 0 & 0 \\
\hline & Mean $^{+}$ & -0.08 & 47 & -8 & - & -17 & 8 & 0.1 & -27 \\
\hline
\end{tabular}

a Weighted average over studied depth.

lower level of terrace. This is probably due to the chemical weathering of mica minerals releasing $\mathrm{K}$ in soils.

\section{Conclusions}

Soils on the marine terrace of the eastern coast of Taiwan provide a good opportunity to study the time-dependent changes in soil development by soil morphological characteristics, micromorphological features, physical and chemical properties, and mass-balance changes. Soil properties on the elevated marine terraces vary systematically with terrace ages. Structures, stress coatings and slickensides are more developed with time. Strong developed angular blocky structure, pressure faces and slickensides are more common in higher terrace soils (9-10 ka). Additionally, micromorphological features support field observations. In this study, including depth to $\mathrm{C}$ horizon, solum thickness, and thickness of the clay-enriched zone show increase with relative terrace age. Although only one to two profiles per terrace were characterized, the following soil properties increase with time: the degree of sand grains weathering, $\mathrm{pH}\left(\mathrm{H}_{2} \mathrm{O}\right)$, organic carbon, $\mathrm{CEC}$, contents of $\mathrm{Fe}_{\mathrm{d}}, \mathrm{Fe}_{\mathrm{o}}$ and $\mathrm{Mn}_{\mathrm{d}}$, respectively. Based on X-ray diffraction analysis of the clay-size fraction, soils on all terraces have a mixed mineralogy. Chlorite, gibbsite and quartz minerals show no considerable change with time. The abundances of mica, smectite, and kaolinite have slightly increased with terrace age. Titanium appears to be a reasonable index element and permits quantification of element gain or loss along the marine terraces in the present work. Positive strain values (dilation) occurred in upper terrace $(9-10 \mathrm{ka})$ and intermediate terrace (5-6 ka), and lightly negative strain values (collapse) only occurred in lower terrace $(\leq 3.5 \mathrm{ka})$. The dominant processes in the intermediate terrace $(5-6 \mathrm{ka})$ and lower terrace $(\leq 3.5 \mathrm{ka})$ identified with mass-balance analysis include loss of bases ( $\mathrm{Ca}$ and $\mathrm{Mg}$ ), $\mathrm{Fe}$, and clay with time. This is 
probably due to the considerable leaching processes. The net gains of $\mathrm{Fe}, \mathrm{Al}$, and $\mathrm{Si}$ in the higher terrace (9-10 ka) increase with time, which are in relation to the relative abundance of kaolinite and gibbsite. The soil properties which do not have notable changes with time are primarily due to the young soil age $(<10 \mathrm{ka})$ of this study.

\section{Acknowledgements}

The authors would like to thank the National Science Council of the Republic of China, Taiwan for financially supporting this research under Contract No. 92-2313-B-020018 and 92-2313-B-197-009.

\section{References}

Birkeland, P.W., 1999. Soils and Geomorphology. Oxford Univ. Press, London. $430 \mathrm{pp}$.

Bockheim, J.G., Kelsey, H.M., Marshall III, J.G., 1992. Soil development, relative dating and correlation of late Quaternary marine terraces in southwestern Oregon. Quat. Res. 37, 60-74.

Bockheim, J.G., Marshall, J.G., Kelsey, H.M., 1996. Soil-forming processes and rates on uplifted marine terraces in southern Oregon, USA. Geoderma 73, $39-62$.

Brimhall, G.H., Dietrich, W.E., 1987. Constitutive mass balance relations between chemical composition, volume, density, porosity, and strain in metasomatic hydrochemical systems: results on weathering and pedogenesis. Geochim. Cosmochim. Acta 51, 567-587.

Brimhall, G.H., Lewis, C.J., Ague, J.J., Dietrich, W.E., Hampel, J., Teague, T., Rix, P., 1988. Metal enrichment in bauxites by deposition of chemically mature aeolian dust. Nature 333, 819-824.

Brimhall, G.H., Chadwick, O.A., Lewis, C.J., Compston, W., Williams, I.S., Danti, K.J., Dietrich, W.E., Power, M.E., Hendricks, D., Bratt, J., 1991a. Deformational mass transport and invasive processes in soil evolution. Science 255, 695-702.

Brimhall, G.H., Lewis, C.J., Ford, C., Bratt, J., Taylor, G., Warin, O., 1991 b. Quantitative geochemical approach to pedogenesis: importance of parent material reduction, volumetric expansion, and eolian influx in lateritization. Geoderma 51, 51-91.

Brindley, G.W., 1980. Quantitative X-ray mineral analysis of clays. In: Brindley, G.W., Brown, G. (Eds.), Crystal Structures of Clay Minerals and Their X-ray Identification. Mineralogical Society, London, pp. 411-438.

Brown, G., Brindley, G.W., 1980. X-ray diffraction procedures for clay mineral identification. In: Brindley, G.W., Brown, G. (Eds.), Crystal Structures of Clay Minerals and Their X-ray Identification. Mineralogical Society, London, pp. 305-359.

Bullock, P., Fedoroff, N., Jongerius, A., Stoops, G., Tursina, T., 1985. Handbook for Thin Section Description. Waine Res. Publ, Albrighton, England. 152pp.

Busacca, A.J., Singer, M.J., 1989. Pedogenesis of a chronosequence in the Sacramento Valley, California, USA, II. Elemental chemistry of silt fractions. Geoderma 44, 43-75.

Chadwick, O.A., Brimhall, G.H., Hendricks, D.M., 1990. Froma black box to grey box - a mass balance interpretation of pedogenesis. Geomorphology 3, 369-390.

Driese, S.D., Mora, C.I., Stiles, C.A., Joeckel, R.M., Nordt, L.C., 2000. Massbalance reconstruction of a modern Vertisol: implications for interpreting the geochemistry and burial alteration of paleo-Vertisols. Geoderma 95, 179-204.

Gee, G.W., Bauder, J.W., 1986. Particle-size analysis. In: Klute, A., et al. (Eds.), Methods of Soil Analysis, Part 1, 2nd ed. Agronomy Monograph, vol. 9. ASA and SSSA, Madison, WI, pp. 383-411.

Ho, C.S., 1988. An Introduction to the Geology of Taiwan Explanatory Text of the Geologic Map of Taiwan, 2nd ed. Cent. Geol. Surv, Taipei, Taiwan. $164 \mathrm{pp}$.
Hsieh, M.L., Liew, P.M., Hsu, M.Y., 2004. Holocene tectonic uplift on the Huatung coast, eastern Taiwan. Quat. Int. 115-116, 47-70.

Hsu, M.Y., 1988. A geomorphological study of marine terraces in Taiwan. Ph.D. Thesis, Institute of Earth Science, Chinese Culture University, Taipei, Taiwan. (in Chinese, with English Abstract).

Huggett, R.J., 1998. Soil chronosequences, soil development, and soil evolution: a critical review. Catena 32, 155-172.

ISSS Working Group, 1998. World Reference Base for Soil Resources: Introduction. In: Deckers, J.A., Nachtergaele, F.D., Spaargaren, O.C. (Eds.), First Ed. ISSS-ISRIC-FAO, Acco, Leuven.

Jenny, H., 1941. Factors in Soil Formation. McGraw-Hill, New York. 281pp.

Karathanasis, A.D., Macneal, B.R., 1994. Evaluation of parent material uniformity criteria in loess-influenced soils of west-central Kentucky. Geoderma 64, 73-92.

Langley-Turnbaugh, S.J., Bockheim, J.G., 1998. Mass balance of soil evolution on late Quaternary marine terraces in coastal Oregon. Geoderma 84, 265-288.

Liew, P.M., Hsieh, M.L., Shyu, B.H., 2004. An overview of coastal development in a Young Mountain Belt-Taiwan. Quat. Int. 115-116, 39-45.

Matthews, J.A., Dresser, P.Q., 1983. Intensive ${ }^{14} \mathrm{C}$ dating of a buried palaeosol horizon. Geol. Foren. Stockh. Forh. 105, 59-63.

McKeague, J.A., Day, J.H., 1966. Dithionite and oxalate extractable Fe and Al as aids in differentiating various classes of soils. Can. J. Soil Sci. 46, 13-22.

McLean, E.O., 1982. Soil pH and lime requirement. In: Page, A.L., et al. (Eds.), Methods of Soil Analysis, Part 2, 2nd ed. . Agronomy Monograph, vol. 9. ASA and SSSA, Madison, WI, pp. 199-224.

Mehra, O.P., Jackson, M.L., 1960. Iron oxides removed from soils and clays by a dithionite-citrate system buffered with sodium bicarbonate. Clays Clay Miner. 7, 317-327.

Merritts, D.J., Chadwick, O.A., Hendricks, D.M., 1991. Rates and processes of soil evolution on uplifted marine terraces, northern California. Geoderma 51, 241-275.

Milnes, A.R., Fitzpatrick, R.W., 1989. Titanium and zirconium minerals. In: Dixon, J.B., Weed, S.B. (Eds.), Minerals in Soil Environments. SSSA Book Ser., vol. 1. SSSA, Madison, WI, pp. 1131-1208.

Moody, L.E., Graham, R.C., 1995. Geomorphic and pedogenic evolution in coastal sediments, central California. Geoderma 67, 181-201.

Muhs, D.R., 1982. A soil chronosequence on Quaternary marine terraces, San Clemente Island, California. Geoderma 28, 257-283.

Muhs, D.R., 2001. Evolution of soils on Quaternary reef terraces of Barbados, West India. Quat. Res. 56, 66-78.

Nelson, R.E., 1982. Carbonate and gypsum. In: Page, A.L., Miller, R.H., Keeney, D.R. (Eds.), Methods of Soil Analysis, Part 2, 2nd ed. Agron. Monogr., vol. 9. Agronomy Society of America and Soil Science Society of America, Madison, WI, pp. 181-197.

Nelson, D.W., Sommers, L.E., 1982. Total carbon, organic carbon, and organic matter. In: Page, A.L., et al. (Eds.), Methods of Soil Analysis, Part 2, 2nd ed. Agronomy Monograph, vol. 9. ASA and SSSA, Madison, WI, pp. 539-577.

Nettleton, W.D., Sleeman, J.R., 1985. Micromorphology of Vertisols. In: Douglas, L.A., Thompson, M.L. (Eds.), Soil Micromorphology and Soil Classification. SSSA special Publication, vol. 15. SSSA, Madison, WI, pp. 165-196.

Nieuwenhuyse, A., Van Breemen, N., 1997. Quantitative aspects of weathering and neoformation in selected Costa Rica volcanic soils. Soil Sci. Soc. Am. J. $61,1450-1458$.

Nordt, L.C., Wilding, L.P., Lynn, W.C., Crawford, C.C., 2004. Vertisol genesis in a humid climate of the coastal plain of Texas, U.S.A. Geoderma 122, 83-102.

Oh, N.H., Richter, D.D., 2005. Elemental translocation and loss from three highly weathered soil-bedrock profiles in the southeastern United States. Geoderma 126, 5-25.

Rhoades, J.D., 1982. Cation exchange capacity. In: Page, A.L., et al. (Eds.), Methods of Soil Analysis, Part 2, 2nd ed. Agronomy Monograph, vol. 9. ASA and SSSA, Madison, WI, pp. 149-157.

Schaetzl, R.J., 1998. Lithologic discontinuities in some soils on drumlins: theory, detection, and application. Soil Sci. 163, 570-590.

Shih, T.T., Teng, K.H, Hsu, M.Y., Yang, G.S., 1988. A geomorphological study of marine terrace in Huatung coast of Taiwan. Geogr. Res. 14, 1-50 (in Chinese with English abstract).

Smeck, N., Wilding, L., 1980. Quantitative evaluation of pedon formation in calcareous glacial deposits in Ohio. Geoderma 24, 1-16. 
Soil Survey Division Staff, 1993. Soil Survey Manual. U.S.D.A. Agric. Handbook, vol. 18. U.S. Govt. Print. Office, Washington, DC.

Soil Survey Division Staff, 2006. Keys to Soil Taxonomy, (10th ed.), U.S. Dep. Agric., Soil Conserv. Serv., Washington, DC.

Sommer, M., Stahr, K., 1996. The use of element:clay-ratios assessing gains and losses of iron, manganese and phosphorus in soils of sedimentary rocks on a landscape scale. Geoderma 71, 173-200.

Stolt, M.H., Baker, J.C., Simpson, T.W., 1993. Soil landscape relationships in Virginia: 1. Soil variability and parent material uniformity. Soil Sci. Soc. Am. J. 57, 414-421.
Tsai, C.C., Chen, Z.S., 2000. Lithologic discontinuity in Ultisols along a toposequence in Taiwan. Soil Sci. 165, 587-596.

Vreeken, W.J., 1975. Principal kinds of chronosequences and their significance in soil history. J. Soil Sci. 26, 378-394.

West, L.T., Wilding, L.P., Stahnke, C.R., Hallmark, C.T., 1988. Calciustolls in central Texas: 1. Parent material uniformity and hillslope effects on carbonate-enriched horizons. Soil Sci. Soc. Am. J. 52, 1722-1731. 